3. Presecki P, Muck-Seler D, Mimica N, et al. Serum lipid levels in patients with Alzheimer's disease. Coll Antropol 2011;35(suppl 1):115-120.

4. Rea TD, Breitner JC, Psaty BM, et al. Statin use and the risk of incident dementia: the Cardiovascular Health Study. Arch Neurol 2005;62:1047-1051.

5. Li G, Higdon R, Kukull WA, et al. Statin therapy and risk of dementia in the elderly: a community-based prospective cohort study. Neurology 2004;63:1624-1628.

6. Arvanitakis Z, Schneider JA, Wilson RS, et al. Statins, incident Alzheimer's disease, change in cognitive function, and neuropathology. Neurology 2008;70:1795-1802.

7. Haag MDM, Hofman A, Koudstaal PJ, Stricker BHC, Breteler MMB. Statins are associated with a reduced risk of Alzheimer disease regardless of lipophilicity: The Rotterdam Study. J Neurol Neurosurg Psychiatry 2009; 80:13-17.

\section{LONGITUDINAL ASSESSMENT OF OXALIPLATIN-INDUCED NEUROPATHY}

Susanna B. Park, Martin Koltzenburg, London, UK: The small sample size may have contributed to the finding of Burakgazi et al. ${ }^{1}$ that oxaliplatin produces only mild axonal loss yet others have identified significant axonal loss (greater than 50\% amplitude reduction). ${ }^{2}$ It is possible that the inclusion of patients with baseline neuropathic symptoms (TNS score $\geq 4$ ) led to a floor effect with respect to changes in sensory amplitudes and nerve function following oxaliplatin.

It was also interesting that reductions in intraepidermal nerve fiber density (IENFD) were reported. These are typically utilized to examine small fiber neuropathy. ${ }^{3}$ Given the prominent large fiber dysfunction identified in oxaliplatintreated patients by clinical and neurophysiologic assessments, the finding of small fiber loss is unexpected. The IENFD changes may be too small to be clinically observable through quantitative sensory testing, ${ }^{4}$ but may be interesting in terms of the pathophysiologic basis for the development of neuropathy. As such, it is important to replicate this finding in a larger sample.

Finally, the impact of long-term nerve damage remains critical, particularly in the adjuvant setting. These results are similar to previous studies where oxaliplatin produced a long-lasting neuropathy, ${ }^{2,5}$ in contrast to the previously held view of reversibility within 6 months.
Copyright (C) 2012 by AAN Enterprises, Inc.

1. Burakgazi AZ, Messersmith W, Vaidya D, et al. Longitudinal assessment of oxaliplatin-induced neuropathy. Neurology 2011;77:980-986.

2. Park SB, Lin CS, Krishnan AV, et al. Long-term neuropathy after oxaliplatin treatment: challenging the dictum of reversibility. Oncologist 2011;16:708-716.

3. Lauria G, Hsieh ST, Johansson O, et al. European Federation of Neurological Societies/Peripheral Nerve Society Guideline on the use of skin biopsy in the diagnosis of small fiber neuropathy. Eur J Neurol 2010;17:e44-e49.

4. Attal N, Bouhassira D, Gautron M, et al. Thermal hyperalgesia as a marker of oxaliplatin neurotoxicity: A prospective quantified sensory assessment study. Pain 2009; 144:245-252.

5. Land SR, Kopec JA, Cecchini RS, et al. Neurotoxicity from oxaliplatin combined with weekly bolus fluorouracil and leucovorin as surgical adjuvant chemotherapy for stage II and III colon cancer: NSABP C-07. J Clin Oncol 2007; 25:2205-2211.

\section{NORMAL PRESSURE HYDROCEPHALUS: HOW OFTEN DOES THE DIAGNOSIS HOLD WATER?}

Richard B. Rosenbaum, Portland, OR: This arti$\mathrm{cle}^{1}$ and the accompanying podcast were excellent. Can the authors clarify how soon after the high volume lumbar puncture the patient is examined and how long the effect lasts? For example, is test sensitivity lost if the examination is done 1 hour after the lumbar puncture?

Author Response: Bryan T. Klassen, Rochester, MN: At our institution, the patients are evaluated with videotaped gait examinations immediately before and shortly after ( $\sim 30$ minutes) the high volume lumbar puncture. They are generally seen the following day by the physician who elicits the patient/family's impression of results, views the videos, and repeats the examination. The decision to proceed with surgery was based upon a clearly favorable response to the lumbar puncture, whether or not this was sustained the following day. We did not have sufficient data to explore the question of how the test's sensitivity changes over time.

Copyright (C) 2012 by AAN Enterprises, Inc.

1. Klassen BT, Ahlskog JE. Normal pressure hydrocephalus: how often does the diagnosis hold water? Neurology 2011; 77:1119-1125. 


\section{Neurology}

\section{Longitudinal assessment of oxaliplatin-induced neuropathy \\ Susanna B. Park and Martin Koltzenburg \\ Neurology 2012;78;152 \\ DOI 10.1212/01.wnl.0000410913.88642.bf}

This information is current as of January 9, 2012

\section{Updated Information \& Services}

References

Errata

Permissions \& Licensing

Reprints including high resolution figures, can be found at: http://n.neurology.org/content/78/2/152.1.full

This article cites 5 articles, 3 of which you can access for free at: http://n.neurology.org/content/78/2/152.1.full\#ref-list-1

An erratum has been published regarding this article. Please see next page or:

/content/78/7/515.full.pdf

Information about reproducing this article in parts (figures,tables) or in its entirety can be found online at:

http://www.neurology.org/about/about_the_journal\#permissions

Information about ordering reprints can be found online:

http://n.neurology.org/subscribers/advertise

Neurology ${ }^{\circledR}$ is the official journal of the American Academy of Neurology. Published continuously since 1951, it is now a weekly with 48 issues per year. Copyright Copyright (? 2012 by AAN Enterprises, Inc.. All rights reserved. Print ISSN: 0028-3878. Online ISSN: 1526-632X.

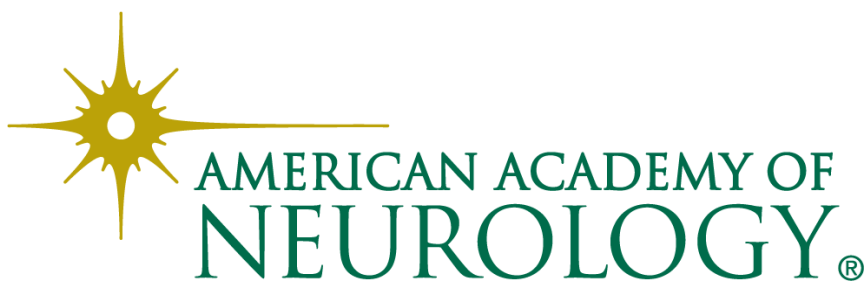


clear analysis of the successes and challenges facing the UCNS. It seems that the ship has sailed in terms of neurology trainees pursuing subspecialization and super subspecialization and this is a trend that will likely continue. This trend has its disadvantages, especially in academic neurology departments. Academic neurology departments are becoming more similar to internal medicine departments with various subspecialty divisions. But what about "general" neurology? I suspect that academic general neurologists are a dying breed, and this problem will only become more acute over time as the current "master clinicians" retire. This will lead to a reduction in general neurology teaching to medical students and residents, as well as a potential loss of clinical revenue to academic departments when the only general neurologists willing to see "undifferentiated" patients are in the community. General neurology is a "specialty" in its own right, yet if residency training in neurology simply becomes a means to an end of subspecialization, then I fear for the future of our specialty as a whole.

Bruce Sigsbee, Rockport, ME: The need for and growth of the UCNS is a reflection of the rapid growth of knowledge in all subspecialty areas of neurology. ${ }^{1}$ However, general neurology is not dying. Rather, the importance of neurologists grounded in the wide spectrum of neurologic disease is expanding. While many neurologic groups are looking for subspecialty expertise, those individuals still need to care for all neurologic patients. Many academic departments are expanding general neurologic sections. Patients do not arrive with labels. The Massachusetts General Neurology Department has a general neurology fellowship.
An AAN general neurology taskforce completed a report to the AAN Board. ${ }^{1}$ One of the key conclusions was that training programs and the AAN must support training and education for the generalist. The rapidly expanding concepts of disease and treatment options create immense challenges for the generalist. Subspecialization in neurology will continue to expand. One of our challenges as a specialty is to figure out how general neurologists can be trained in and remain current in this dynamic specialty.

Author Response: Paul Vespa, Los Angeles; Stephen M. Sergay, Tampa, FL; John H. Kohring, St. Paul: The authors agree with Dr. Sigsbee that the general neurologist is the backbone of the specialty, and that training for the generalist should continue to be supported by the AAN. The UCNS was established as a resource for those who choose subspecialization. We believe that subspecialization complements general neurology. General Neurology is an AAN section which is represented on the Committee on Sections.

Copyright (C) 2012 by AAN Enterprises, Inc.

1. Vespa PM, Sergay SM, Kohring JH. Subspecialization in neurology: the role of the United Council for Neurologic Subspecialties. Neurology 2011;77:1702-1705.

2. The United Council for Neurologic Subspecialties Diplomates. Available at: http://www.ucns.org/go/subspecialty/ diplomates. Accessed November 7, 2011.

3. The United Council for Neurologic Subspecialties. Fellowships. Available at: http://www.ucns.org/apps/directory/index. $\mathrm{cfm}$ ? event $=$ public.program.searchResults\&subspecialty_ids $=$ 4\&inst_state $=\&$ submit $=$ Start + Search. Accessed November 7, 2011.

4. Gesme DH, Wiseman M. Subspecialization in community oncology: option or necessity? J Oncol Pract 2011;7: $199-201$.

\section{CORRECTION}

WriteClick: Longitudinal assessment of oxaliplatin-induced neuropathy

In the WriteClick discussion of "Longitudinal assessment of oxaliplatin-induced neuropathy" by S.B. Park et al. (Neurology ${ }^{\circledR}$ 2012;78:152), there is an omission in the author list, which should have included Cindy S.-Y. Lin and Matthew C. Kiernan. The editorial staff regrets the omission. 